\title{
Sistem Pendukung Keputusan Untuk Tender Alat Kesehatan Di Rumah Sakit PKU Muhammadiyah Sekapuk Gresik
}

\author{
Maulana Ishaq ${ }^{1}$, Dwi Cahyono ${ }^{2}$, Ratna Nur Tiara Shanty ${ }^{3}$ \\ ${ }^{1}$.mlana1819@gmail.com, ${ }^{3}$.ratnanurtiara@gmail.com
}

Program Studi Teknik Informatika, Universitas Dr.Soetomo Surabaya

\begin{abstract}
Abstrak-Tender for medical devices is one of the procurement activities carried out by PKU Muhammadiyah Sekapuk Gresik Hospital aimed at fulfilling the need to improve its services. The hospital often has difficulty in carrying out the tender process. One of them is in determining the tender participant company that has the right to qualify for the presentation stage because the previous election was only based on instinct so that it could cause the tender process to last long. Therefore, special management is needed by applying information technology as decision support to determine the companies that pass the initial selection. In this Final Project, the Web-based "Decision Support System for Tender for Medical Devices" was developed using the PHP programming language and using the Technique for Order Preference by Similarity to Ideal Solution (TOPSIS) method that can select and recommend companies based on criteria which have been specified. This research was able to facilitate the hospital in selecting bidders in the procurement process by providing output in the form of ranking that can be made a priority in decision making.
\end{abstract}

Instisari-Tender alat kesehatan merupakan salah satu kegiatan pengadaan yang dilakukan oleh Rumah Sakit PKU Muhammadiyah Sekapuk Gresik bertujuan untuk memenuhi kebutuhan dalam meningkatkan pelayanannya. Pihak rumah sakit sering mengalami kesulitan dalam menjalankan proses tender. Salah satunya dalam menentukan perusahaan peserta tender yang berhak lolos ke tahapan presentasi karena pemilihan sebelumnya hanya berdasarkan insting semata, sehingga dapat menyebabkan proses tender berlangsung lama. Oleh karena itu, dibutuhkan suatu pengelolaan khusus dengan menerapkan teknologi informasi sebagai pendukung keputusan untuk menentukan perusahaan yang lolos seleksi tahap awal.Pada Tugas Akhir ini dibuatlah "Sistem Pendukung Keputusan untuk Tender Alat Kesehatan" berbasis Web yang dikembangkan ini menggunakan bahasa pemrograman PHP dan menggunakan metode Technique for Order Preference by Similarity to Ideal Solution (TOPSIS) yang dapat melakukan seleksi dan merekomendasikan perusahaan peserta tender berdasarkan dengan kriteria yang telah ditentukan. Penelitian ini mampu untuk memudahkan pihak rumah sakit dalam melakukan seleksi perusahaan peserta tender dalam proses pengadaan dengan cara memberikan output berupa perangkingan yang dapat dijadikan prioritas dalam pengambilan keputusan.

Kata Kunci-Tender Alat Kesehatan, Sistem Pendukung Keputusan, TOPSIS, PHP.

\section{PENDAHULUAN}

Pengadaan barang / jasa bernilai besar atau yang lebih dikenal dengan pelelangan (tender) merupakan sebuah proses pengadaan dari proyek tertentu[1], seperti proyek pada pengadaan alat kesehatan pada rumah sakit yang bernilai besar. Tender barang / jas a yang dilakukan bersifat umum dari pengadaan alat kesehatan seperti pengadaan Mesin CT-Scan pada unit pelayanan radiologi pada rumah sakit[1][2].

Sebagai salah satu program dari rumah sakit untuk meningkatkan mutu pelayanan serta melakukan pembaruan alat dan fasilitas maka proses pengadaan sangat diperlukan [3]. Pengadaan alat kesehatan di Rumah Sakit PKU Muhammadiyah Sekapuk Gresik ini akan dilakukan tender jika besaran nilai investasi yang harus dikeluarkan pihak rumah sakit bernilai minimum dari Rp. 200.000.000. Proses tender pengadaan alat kesehatan yang ada di Rumah Sakit Muhammadiyah Sekapuk terdapat dua tahapan, yakni tahapan seleksi awal untuk menentukan peserta tender yang akan masuk ke tahap presentasi dan tahap presentasi untuk menentukan pemenang tender. Proses seleksi pada tahap awal yang dilakukan di Rumah Sakit Muhammadiyah Sekapuk saat ini bersifat subjektif dengan langsung mempertemukan perusahaan peserta tender sebagai pihak penyedia barang / jasa dengan pihak rumah sakit sebagai pengguna barang / jasa. Proses tersebut memiliki beberapa kekurangan, seperti proses yang terjadi akan berlangsung lebih lama jika perusahaan penyedia barang / jasa (peserta lelangyang memberikan penawaran berjumlah banyak, maka akan membutuhkan waktu yang lama untuk melakukan proses seleksinya)[1][2], selain itu dapat memungkinkan untuk terjadi sebuah kesalahan 
dalam menentukan peserta tender yang lolos seleksi tahap awal dan terkesan tidak fair, karena proses pemilihannya dengan menduga-duga sehingga hal ini dapat menimbulkan kerugian pihak rumah sakit[4].

Sistem pendukung keputusan dapat dijadikan sebagai salah satu pendekatan untuk menyelesaikan masalah[5]. Sistem pendukung keputusan diharapkan dapat memberikan solusi ke pihak rumah sakit agar dapat mempermudah dalam memustuskan peserta tender yang akan lolos ke tahap presentasi sebagai tahap terakhir dari pihak rumah sakit untuk dapat menentukan pemenang dari tender proyek yang berlangsung[5][6].Meskipun sistem pendukung keputusan tidak selalu tepat, namun sistem ini diperlukan dalam mempermudah proses pengambilan keputusan karena berdasarkan perhitungan[7] yang matang lebih baik jika dibandingkan dengan keputusan yang diambil secara subjektif atau hanya berdasarkan insting semata[8].

Berdasarkan penelitian sebelumnya yaitu "Sistem Pendukung Keputusan Evaluasi Pemilihan Pemenang Pengadaan Aset dengan Metode SAW" [9], kriteria yang akan digunakan untuk proses perhitungan ini ialah evaluasi teknis, evaluasi administrasi dan evaluasi harga[10]. Sedangkan untuk memenuhi kebutuhan dari Rumah Sakit PKU Muhammadiyah Sekapuk, penelitian ini akan menerapkan 7 kriteria dengan berdasarkan harga penawaran, sistem pembayaran, kesesuaian spesifikasi, garansi produk, kontak service, branded atau pabrikan, dan populasi produk.

Berdasarkan permasalahan yang ada maka dibutuhkan Sistem Pendukung Keputusan untuk Tender Alat Kesehatan dengan menggunakan metode Technique for Order Preference by Similarity to Ideal Solution (TOPSIS)[2]. TOPSIS merupakan suatu bentuk metode pendukung keputusan yang didasarkan pada konsep bahwa alternatif yang terbaik tidak hanya memiliki jarak terpendek dari solusi ideal positif, namun juga memiliki jarak terpanjang dari solusi ideal negatif [11][12]. Dalam hal ini akan memberikan keputusan mengenai penentuan peserta tender yang lolos seleksi tender alat kesehatan tahap awal, karena dalam proses pengadaan alat kesehatan ini memiliki kriteria pemilihan bukan hanya pada kondisi alat dalam jangka pendek, namun juga ditentukan dalam pemeliharaan alat yang memiliki kriteria untuk jangka panjang, sehingga penerapan metode TOPSIS dapat menjadi solusi[11][12].

\section{METODE PENELITIAN}

Metodologi penelitian yang dilakukan ini adalah metode penelitian dengan tahapan penelitian seperti berikut :

1 Mengidentifikasi masalah, peluang, dan tujuan

Tahap pertama dari siklus SDLC adalah mengidentifikasi masalah, peluang, dan tujuan-tujuan yang hendak dicapai.Pencetusan masalah dan tujuan yang tepat, memungkinkan adanya peluang yang tepat sasaran. Masalah yang timbul di Rumah Sakit PKU Muhammadyah Sekapuk ialah adanya kesulitan yang dialami pihak rumah sakit dalam menyeleksi peserta tender yang akan masuk ke tahap awal atau tahap presentasi karena sistem yang ada hanya berdasarkan insting semata dan bersifat subjektif. Oleh karena itu, dibangunlah Sistem Pendukung Keputusan untuk Tender Alat Kesehatan agar memudahkan pihak rumah sakit dalam melakukan seleksi tahap awaldengan tepat sasaran sesuai dengan penilaian berdasarkan kriteria yang telah ditentukan.

2. Menentukan syarat-syarat informasi

Syarat-syarat informasi dalam pembangunan Sistem Pendukung Keputusan untuk Tender Alat Kesehatan dapat ditempuh dengan caramemasukkan data penilaian dari setiap kriteria yang ada berdasarkan data penawaran yang telah dimasukkan oleh Perusahaan peserta tender.

\section{Menganalisis kebutuhan sistem}

Dalam perancangan dan pengembangan suatu sistem, menganalisis kebutuhan juga merupakan tahap yang cukup penting. Analisis kebutuhan yang terstruktur ini dapat disajikan dengan diagram aliran data yang menampilkan input, proses dan output. Input yang dibutuhkan pada Sistem Pendukung Keputusan untuk Tender Alat Kesehatan di Rumah Sakit PKU Muhammadiyah Sekapuk ini meliputidata harga penawaran, sistem pembayaran, kesesuaian spesifikasi, garansi produk, kontrak service, branded atau pabrikan, populasi produk.

\section{Merancang sistem yang direkomendasikan}

Pada tahap ini peneliti merancang prosedur data-entry sedemikian rupa, sehingga data yang diinputke dalam sistem informasi benar-benar akurat. Perancangan sistem ini adalah gambaran umum antarmuka antara sistem dengan user. Antarmuka tersebut dirancang sedemikian rupa untuk menciptakan kesan friendly bagi pemakainya[13]. Tahap perancangan Sistem Pendukung Keputusan untuk Tender Alat Kesehatan tidak hanya terfokus pada antarmuka, namun juga meliputi perancangan basisdata dan output yang dihasilkan.

\section{Mengembangkan dan mendokumentasikan perangkat lunak}

Pada tahapan SDLC yang kelima, peneliti mulai melakukan pengembangan Sistem Pendukung Keputusan untuk Tender Alat Kesehatan di RS PKU Muhammadiyah Sekapuk dengan bahasa pemrograman. Bahasa pemrogaman yang digunakan dalam pengambangan sistem ini adalah PHP.Fungsi dari pengembangan perangkat lunak dalam tahapan ini adalah sebagai penghubung antara perangkat keras dengan penggunanya.

6. Menguji dan mempertahankan sistem

Sebelum Sistem Pendukung Keputusan untuk Tender Alat Kesehatandiimplementasikan ke pengguna, peneliti melakukan pengujian sistem terlebih dahulu untuk mengidentifikasi masalah-masalah yang mungkin muncul.

\section{Mengimplementasikan dan mengevaluasi system}

Implementasi sistem meliputi pengubahan file-file dari format lama ke format baru, menginstal berbagai kebutuhan 
sistem pada calon penggunanya.Selain itu, tindakan evaluasi juga perlu dilakukan guna mengetahui kelebihan dan kelemahan dari Sistem Pendukung Keputusan Prioritas untuk Tender Alat Kesehatan yang telah dikembangkan.

\section{HASIL DAN PEMBAHASAN}

Penelitian ini bertujuan untuk melakukan proses seleksi danMerekomendasikan perusahaan-perusahaanpeserta tender alat kesehatan yang layak lolos seleksi tahap awaldalam sebuah pengadaan alat kesehatan di Rumah Sakit PKU Muhammadiyah Sekapuk Gresik dengan memanfaatkan metode TOPSIS.

Adapun proses analisis dengan menggunakan metode TOPSIS ditunjukkan oleh flowchart berikut ini:

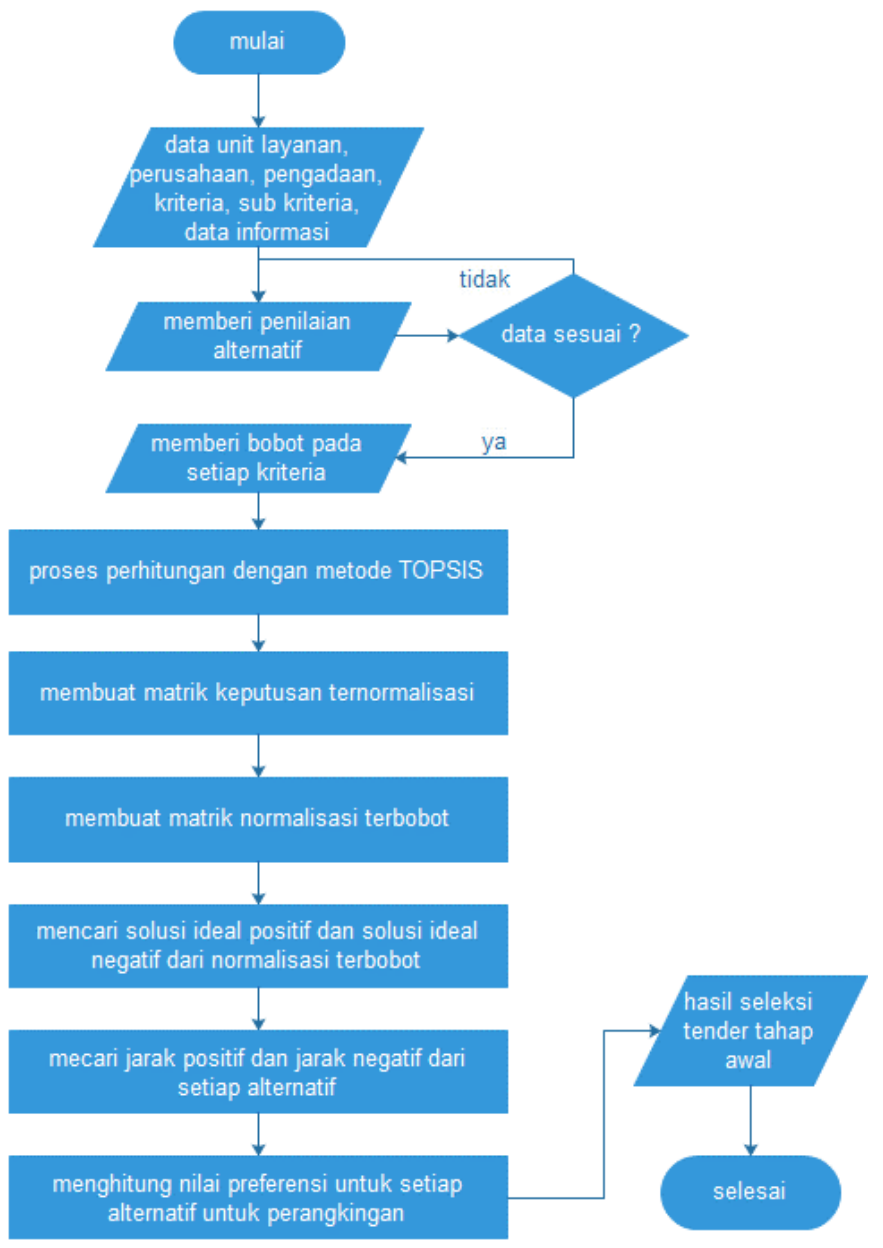

Gambar 1. Flowchart Metode TOPSIS

1) Memasukkan data-data yang diperlukan

Memasukkan data unit pelayanan, data perusahaan, data kriteria, data sub kriteria, data pengadaan dan data informasi.

2) Memasukkan nilai dari setiap alternatif yang ada

Memasukkan penilaian kepada perusahaan peserta tender yang menjadi alternatif.Penilaian berdasarkan pada proposal penawaran yang telah diajukan oleh perusahaan tersebut.

3) Menentukan bobot kriteria

Memasukkan nilai bobot pada masing-masing kriteria untuk menentukan prioritas kriteria yang ada.

4) Menentukan normalisasi matriks keputusan

Normalisasi matriks keputusan diperoleh dari hasil pembagian antara data tiap subkriteria pada tiap alternatif dengan akar hasil pangkat yang kemudian dijumlahkan dari tiap kriteria.

5) Menentukan normalisasi terbobot

Normalisasi terbobot diperoleh dari hasil perkalian antara data hasil normalis asi dengan bobot kriteria.

6) Menentukan matriks solusi ideal positif dan matriks solusi ideal negatif

Mencari nilai tertinggi dan terendah dari normalisasi terbobot.Nilai tertinggi tersebut dijadikan sebagai solusi ideal positif dan nilai terendah menjadi solusi ideal negatif.

7) Mencari jarak setiap alternatif

Untuk mencari jarak dari setiap alternatif untuk solusi ideal positif dan solusi ideal negatif

8) Menentukan nilai preferensi

Menentukan nilai preferensi merupakan penentuan dari hasil perhitungan Sistem Pendukung Keputusan dengan metode TOPSIS.Nilai preferensi ini dijadikan sebagai nilai akhir untuk perangkingan dari setiap alternatif yang diseleksi.

\section{A. Menentukan Kriteria untuk Tender Alat Kesehatan}

Proses analis is Sistem Pendukung Keputusan untuk Tender Alat Kesehatan dimulai dengan menentukan kriteria-kriteria yang dijadikan sebagai penilaian terhadap proses penyeleksian perusahaan peserta tender.

Kriteria yang digunakan pada penelitian ini ialah harga penawaran, sistem pembayaran, kesesuaian spesifikasi, garansi produk, kontrak service, branded atau pabrikan dan populasi produk.

Data-data yang digunakan dalam uji coba sistem hanya dari beberapa data sampel yang akan diuji yang dapat dilihat pada table berikut:

TABEL I

DAFTAR KRITERIA

\begin{tabular}{|c|l|}
\hline No. & \multicolumn{1}{|c|}{ Kriteria } \\
\hline 1 & Harga Penawaran \\
\hline 2 & Sistem Pemabayaran \\
\hline 3 & Kesesuaian Spesifikasi \\
\hline 4 & Garansi Produk \\
\hline 5 & Kontrak Service \\
\hline 6 & Branded atau Pabrikan \\
\hline 7 & Populasi Produk \\
\hline
\end{tabular}

\section{B. Pembobotan Tiap Kriteria}

Langkah selanjutnya ialah melakukan pembobotan masing-masing kriteria.Bobot kriteria pada uji coba implementasi sistem ini mengacu pada pengadaan alat 
kesehatan pada unit pelayanan radiologi di rumah sakit PKU Muhammadiyah Sekapuk Gresik Adapun tabel bobot kriteria ialah sebagai berikut.

TABEL II BOBOT KRITERIA

\begin{tabular}{|c|c|}
\hline Kriteria & Bobot \\
\hline Harga Penawaran & 20 \\
\hline Sistem Pemabayaran & 20 \\
\hline Kesesuaian Spesifikasi & 15 \\
\hline Garansi Produk & 15 \\
\hline Kontrak Service & 10 \\
\hline Branded atau Pabrikan & 10 \\
\hline Populasi Produk & 10 \\
\hline
\end{tabular}

Bobot penilaian pada masing-masing sub kriteria ialah sebagai berikut.

1. Harga Penawaran

Kriteria yang pertama adalah kriteria harga penawaran. Kriteria ini nilai adalah nominal biaya atau besaran nilai investasi yang harus dikeluarkan oleh pihak rumah sakit dalam sebuah proses pengadaan alat kesehatan.

TABEL III

BOBOT SUBKRITERIA HARGA PENAWARAN

\begin{tabular}{|l|c|c|}
\hline \multicolumn{1}{|c|}{ Subkriteria } & Bobot Nilai & Keterangan \\
\hline $\begin{array}{l}\text { Rp.200.000.000 } \\
\text { Rp.500.000.000 }\end{array}$ & 5 & Sangat Baik \\
\hline $\begin{array}{l}\text { Rp.500.000.000 - } \\
\text { Rp.750.000.000 }\end{array}$ & 4 & Baik \\
\hline $\begin{array}{l}\text { Rp.750.000.000 - } \\
\text { Rp.1.000.000.000 }\end{array}$ & 3 & Cukup \\
\hline $\begin{array}{l}\text { Rp.1.000.000.000 - } \\
\text { Rp.1.500.000.000 }\end{array}$ & 2 & Kurang Baik \\
\hline $\begin{array}{l}\text { Rp.1.500.000.000 - } \\
\text { Rp.2.000.000.000 }\end{array}$ & 1 & Tidak Baik \\
\hline
\end{tabular}

2. Sistem Pembayaran

Faktor ini menyangkut berapa kali tahapan pembayaran yang harus dilakukan oleh rumah sakit.

TABEL IV

BOBOT SUBKRITERIA SISTEM PEMBAYARAN

\begin{tabular}{|l|c|c|}
\hline \multicolumn{1}{|c|}{ Subkriteria } & Bobot Nilai & Keterangan \\
\hline 12 Termin & 5 & Sangat Baik \\
\hline 6 Termin & 4 & Baik \\
\hline 3 Termin & 3 & Cukup \\
\hline 2 Termin & 2 & Kurang Baik \\
\hline Cash / Langsung & 1 & Tidak Baik \\
\hline
\end{tabular}

3. Kesesuaian Spesifikasi

Faktor ini menyangkut spesifikasi alat yang ditawarkan oleh perusahaan ke rumah sakit

$$
\text { TABEL V }
$$

BOBOT SUBKRITERIA KESESUAIAN SPESIFIKASI

\begin{tabular}{|l|c|c|}
\hline \multicolumn{1}{|c|}{ Subkriteria } & Bobot Nilai & Keterangan \\
\hline $\begin{array}{l}\text { Spesifikasi sesuai } \\
\text { permintaan }\end{array}$ & 5 & Sangat Baik \\
\hline Spesifikasi lebih tinggi & 4 & Baik \\
\hline Spesifikasi lebih rendah & 3 & Cukup \\
\hline
\end{tabular}

4. Garansi Produk

Faktor ini menyangkut berapa lama masa garansi service yang di berikan untuk ke pihak rumah sakit.

TABEL VI

BOBOT KRITERIA GARANSI PRODUK

\begin{tabular}{|l|c|l|}
\hline \multicolumn{1}{|c|}{ Subkriteria } & Bobot Nilai & \multicolumn{1}{c|}{ Keterangan } \\
\hline 18 Bulan & 5 & Sangat Baik \\
\hline 12 Bulan & 4 & Baik \\
\hline 9Bulan & 3 & Cukup \\
\hline 6 Bulan & 2 & Kurang Baik \\
\hline 3 Bulan & 1 & Tidak Baik \\
\hline
\end{tabular}

5. Kontrak Service

Faktor ini menyangkut sistem pemeliharaan alat atau setelah masa garansi telah habis.Faktor ini sebagai acuan untuk rumah sakit dalam jangka panjang untuk pemeliharaan alat, sehingga rumah sakit dapat kejelasan dari perusahaan penyedia alat untuk pemeliharaan alat di saat masa garansi telah habis.

TABEL VII

BOBOT SUBKRITERIA KONTRAK SERVICE

\begin{tabular}{|l|c|l|}
\hline \multicolumn{1}{|c|}{ Subkriteria } & Bobot Nilai & \multicolumn{1}{c|}{ Keterangan } \\
\hline Ada dan Terlampir & 5 & Sangat Baik \\
\hline Ada tapi tidak Terlampir & 3 & Cukup \\
\hline Tidak Ada & 1 & Kurang Baik \\
\hline
\end{tabular}

6. Branded atau Pabrikan

Faktor ini menyangkut kualitas dan ketenaran merk, serta lokasi pembuatan dari alat kesehatan yang ditawarkan.

TABEL VIII

BOBOT SUBKRITERIA BRANDED ATAU PABRIKAN

\begin{tabular}{|l|c|l|}
\hline \multicolumn{1}{|c|}{ Subkriteria } & $\begin{array}{c}\text { Bobot } \\
\text { Nilai }\end{array}$ & Keterangan \\
\hline $\begin{array}{l}\text { Branded / Eropa dan } \\
\text { Amerika }\end{array}$ & 5 & Sangat Baik \\
\hline Branded / Asia bukan Cina & 4 & Baik \\
\hline
\end{tabular}




\begin{tabular}{|l|l|l|}
\hline Branded / Cina & 3 & Cukup \\
\hline Tidak Branded & 2 & Kurang Baik \\
\hline Tidak Branded / Cina & 1 & Tidak Baik \\
\hline
\end{tabular}

7. Populasi Produk

Faktor ini adalah berapa lama produk ini telah dipasarkan di indonesia dan berapa banyak rumah sakit di Indonesia yang telah menggunakannya, sehingga pihak rumah sakit dapat menanyakan kualitas alat tersebut dengan cara berkomunikasi ke pihak rumahsakit lain yang telah menggunakan alat yang ditawarkan. Sehingga dapat mengetahui kinerja atau kualitas alat yang ditawarkan.

TABEL IX BOBOT SUBKRITERIA POPULASI PRODUK

\begin{tabular}{|l|c|l|}
\hline \multicolumn{1}{|c|}{ Subkriteria } & Bobot Nilai & \multicolumn{1}{|c|}{ Keterangan } \\
\hline$<50$ & 5 & Sangat Baik \\
\hline $35-50$ & 4 & Baik \\
\hline $25-35$ & 3 & Cukup \\
\hline $10-25$ & 2 & Kurang Baik \\
\hline$>10$ & 1 & Tidak Baik \\
\hline
\end{tabular}

8. Nilai KeputusanMasing-Masing Kriteria

Dalam penentuan nilai keputusan masing-masing kriteria, nilai dari masing-masing kriteria dimasukkan ke dalam tabel nilai keputusan yang telah disesuaikan dengan bobot dari tabel subkriteria dari suatu kriteria, sehingga akan diperoleh tabel nilai keputusan sebagai berikut.

TABEL $\mathrm{X}$

NILAI KEPUTUSAN MASING-MASING ALTERNATIF

\begin{tabular}{|c|c|c|c|c|c|c|c|c|}
\hline No & Nama & $\mathbf{K}$ & $\mathbf{K}$ & $\mathbf{K}$ & $\mathbf{K}$ & $\mathbf{K}$ & $\mathbf{K}$ & $\mathbf{K}$ \\
& & $\mathbf{1}$ & $\mathbf{2}$ & $\mathbf{3}$ & $\mathbf{4}$ & $\mathbf{5}$ & $\mathbf{6}$ & $\mathbf{7}$ \\
\hline 1 & Perusahaan 1 & 4 & 5 & 5 & 4 & 3 & 4 & 2 \\
\hline 2 & Perusahaan 2 & 3 & 5 & 4 & 4 & 5 & 3 & 1 \\
\hline 3 & Perusahaan 3 & 4 & 4 & 5 & 5 & 5 & 1 & 2 \\
\hline 4 & Perusahaan 4 & 4 & 4 & 3 & 4 & 3 & 4 & 3 \\
\hline 5 & Perusahaan 5 & 3 & 5 & 5 & 4 & 3 & 3 & 3 \\
\hline
\end{tabular}

\section{Analisa}

Setelah data telah mengalami rating kecocokan tiap kriteria, langkah selanjutnya ialah melakukan proses analisa dengan metode TOPSIS. Adapun langkah-langkah algoritma dari TOPSIS ialah sebagai berikut.

a) Menentukan normalisasi matriks keputusan

Dari hasil tabel VIII, proses perhitungan pertama yang harus dilakukan ialah menentukan normalisasi matriks keputusan, dimana menggunakan rumus sebagai berikut.

$$
r_{i j}=\frac{x_{i j}}{\sqrt{\sum_{i=1}^{m} x_{i j}^{2}}}
$$

Dengan mengambil sampel data dari Perusahaan1, proses perhitungan yang diperoleh ialah sebagai berikut.

$$
\begin{aligned}
& \mathrm{K} 1=\frac{4}{\sqrt{4^{2}+3^{2}+4^{2}+4^{2}+3^{2}}}=\frac{4}{\sqrt{16+9+16+16+9}}=\frac{4}{\sqrt{66}} \\
& =\frac{4}{8,1240384}=0,492365964=0,4924 \\
& \mathrm{~K} 2=\frac{5}{\sqrt{5^{2}+5^{2}+4^{2}+4^{2}+5^{2}}}=\frac{5}{\sqrt{25+25+16+16+25}}=\frac{5}{\sqrt{107}} \\
& =\frac{5}{10,34408084}=0,483368246=0,4834 \\
& \mathrm{~K} 3=\frac{5}{\sqrt{5^{2}+4^{2}+5^{2}+3^{2}+5^{2}}}=\frac{5}{\sqrt{25+16+25+9+25}}=\frac{5}{\sqrt{100}} \\
& =\frac{5}{10}=0,5=0,5000 \\
& \mathrm{~K} 4=\frac{4}{\sqrt{4^{2}+4^{2}+5^{2}+4^{2}+4^{2}}}=\frac{4}{\sqrt{16+16+26+16+16}}=\frac{4}{\sqrt{89}} \\
& =\frac{4}{9,43398113}=0,423999152=0.4240 \\
& \mathrm{~K} 5=\frac{3}{\sqrt{3^{2}+5^{2}+5^{2}+3^{2}+3^{2}}}=\frac{3}{\sqrt{9+25+25+9+9}}=\frac{3}{\sqrt{77}} \\
& =\frac{3}{8,77496439}=0,341881729=0,3419 \\
& \mathrm{~K} 6=\frac{4}{\sqrt{4^{2}+3^{2}+1^{2}+4^{2}+3^{2}}}=\frac{4}{\sqrt{16+9+1+16+9}}=\frac{4}{\sqrt{51}} \\
& =\frac{4}{7,14142843}=0,560112033=0,5601 \\
& \mathrm{~K} 7=\frac{2}{\sqrt{2^{2}+1^{2}+2^{2}+3^{2}+3^{2}}}=\frac{2}{\sqrt{4+1+4+9+9}}=\frac{2}{\sqrt{27}} \\
& =\frac{2}{5,19615242}=0,38490018=0,3849
\end{aligned}
$$

Setelah nilai normalisasi matriks keputusan untuk alternatif Perusahaan 1 ditemukan, proses perhitungan tersebut juga berlaku untuk alternative atau perusahaan lainnya hingga mencatatkan nilai sebagai berikut:

TABEL XI

MATRIKS KEPUTUSAN TERNORMALISASI

\begin{tabular}{|c|c|c|c|c|c|c|c|}
\hline \multirow{2}{*}{ Nama } & \multicolumn{7}{|c|}{ Nilai Kriteria } \\
\cline { 2 - 8 } & $\mathbf{K 1}$ & $\mathbf{K} 2$ & $\mathbf{K 3}$ & $\mathbf{K 4}$ & $\mathbf{K 5}$ & $\mathbf{K 6}$ & $\mathbf{K} 7$ \\
\hline $\begin{array}{c}\text { Perusahaan } \\
1\end{array}$ & $\begin{array}{c}0,4 \\
924\end{array}$ & $\begin{array}{c}0,4 \\
834\end{array}$ & $\begin{array}{c}0,5 \\
000\end{array}$ & $\begin{array}{c}0,4 \\
240\end{array}$ & $\begin{array}{c}0,3 \\
419\end{array}$ & $\begin{array}{c}0,5 \\
601\end{array}$ & $\begin{array}{c}0,38 \\
49\end{array}$ \\
\hline $\begin{array}{c}\text { Perusahaan } \\
2\end{array}$ & 0,3 \\
693 & $\begin{array}{c}0,4 \\
834\end{array}$ & $\begin{array}{c}0,4 \\
000\end{array}$ & $\begin{array}{c}0,4 \\
240\end{array}$ & $\begin{array}{c}0,5 \\
698\end{array}$ & $\begin{array}{c}0,4 \\
201\end{array}$ & $\begin{array}{c}0,19 \\
25\end{array}$ \\
\hline $\begin{array}{c}\text { Perusahaan } \\
3\end{array}$ & 0,4 & 0,3 & 0,5 & 0,5 & 0,5 & 0,1 & 0,38 \\
\hline $\begin{array}{c}\text { Perusahaan } \\
4\end{array}$ & 024 & 867 & 000 & 300 & 698 & 400 & 49 \\
\hline
\end{tabular}




\begin{tabular}{|c|c|c|c|c|c|c|c|c|}
\hline \multirow{2}{*}{ Nama } & \multicolumn{7}{|c|}{ Nilai Kriteria } & \multicolumn{1}{|c|}{} \\
\cline { 2 - 8 } & $\mathbf{K 1}$ & $\mathbf{K 2}$ & $\mathbf{K 3}$ & $\mathbf{K 4}$ & $\mathbf{K 5}$ & $\mathbf{K 6}$ & $\mathbf{K 7}$ \\
\hline $\begin{array}{c}\text { Perusahaan } \\
5\end{array}$ & 0,3 & 0,4 & 0,5 & 0,4 & 0,3 & 0,4 & 0,57 \\
693 & 834 & 000 & 240 & 419 & 261 & 74 \\
\hline
\end{tabular}

b) Membuat matriks keputusan ternormalisasi terbobot

Setelah memperoleh nilai matriks| keputusan ternormalisasi, langkah selanjutnya ialah menghitung matriks keputusan ternormalisasi terbobot dengan rumus

$$
y_{i j}=w_{i} r_{i j}
$$

Caranya ialah dengan mengalikan nilai matriks keputusan ternormalisasi dari suatu alternatif dengan bobot tiap kriteria yang telah ditentukan sebelumnya.

Langkah-langkah perhitungan matriks keputusan normalisasi terbobot yang berlaku untuk Perusahaan 1 tersebut juga berlaku untuk alternatif lainnya, sehingga diperoleh hasil matriks keputusan normalisasi terbobot yang ditunjukkan pada tabel 4.8 berikut.
$\mathrm{K} 1=0,4924 * 20=9,848$
$\mathrm{K} 2=0,4834 * 20=9,668$
$\mathrm{K} 3=0,5000 * 15=7,500$
$\mathrm{K} 4=0,4240 * 15=6,360$
$\mathrm{K} 5=0,3419 * 10=3,419$
$\mathrm{K} 6=0,5601 * 10=5,601$
$\mathrm{K} 7=0,3849 * 10=3,849$

Langkah-langkah perhitungan matriks keputusan ternormalisasi terbobot yang berlaku untuk alternatif Perusahaan 1 tersebut juga berlaku untuk alternatif lainnya, sehingga diperoleh hasil matriks keputusan ternormalisasi terbobot sebagai berikut.

TABEL XII

MATRIKS KEPUTUSAN NORMALISASI TERBOBOT

\begin{tabular}{|c|c|c|c|c|c|c|c|}
\hline \multirow{2}{*}{ Nama } & \multicolumn{7}{|c|}{ Nilai Kriteria } \\
\cline { 2 - 8 } & K1 & K2 & K3 & K4 & K5 & K6 & K7 \\
\hline \multirow{2}{*}{ Perusahaan 1 } & 9,8 & 9,6 & 7,5 & 6,3 & 3,4 & 5,6 & 3,8 \\
& 48 & 68 & 00 & 60 & 19 & 01 & 49 \\
\hline \multirow{2}{*}{ Perusahaan 2 } & 7,3 & 9,6 & 6,0 & 6,3 & 5,6 & 4,2 & 1,9 \\
& 86 & 67 & 00 & 60 & 98 & 01 & 25 \\
\hline \multirow{2}{*}{ Perusahaan 3 } & 9,8 & 7,7 & 7,5 & 7,9 & 5,6 & 1,4 & 3,8 \\
& 47 & 34 & 00 & 50 & 98 & 00 & 49 \\
\hline \multirow{2}{*}{ Perusahaan 4 } & 9,8 & 7,7 & 4,5 & 6,3 & 3,4 & 5,6 & 5,7 \\
& 47 & 34 & 00 & 60 & 19 & 01 & 74 \\
\hline \multirow{2}{*}{ Perusahaan 5 } & 7,3 & 9,6 & 7,5 & 6,3 & 3,4 & 4,2 & 5,7 \\
& 86 & 67 & 00 & 60 & 19 & 01 & 74 \\
\hline
\end{tabular}

c) Menentukan Solusi Ideal Positif dan Solusi Ideal Negatif

Setelah memperoleh nilai perhitungan dari matriks keputusan ternormalisasi terbobot, langkah selanjutnya ialah menentukan solusi ideal positif dan solusi ideal negatif. Solusi ideal positif $(\mathrm{A}+)$ merupakan nilai tertinggi tiap kriteria dari seluruh alternative yang ada, sedangkan solusi ideal negatif (A-) merupakan nilai terendah tiap kriteria dari seluruh alternative yang ada. Proses perhitungan dari langkah sebelumnya, diperoleh :

Rumus untuk mencari solusi ideal positif :

Berdasarkan tabel $\mathrm{X}$, diperoleh solusi ideal positif dan solusi ideal negatif.

TABEL XIII

SOLUSI IDEAL

\begin{tabular}{|c|c|c|c|c|c|c|c|}
\hline $\begin{array}{c}\mathbf{K e} \\
\mathbf{t}\end{array}$ & $\mathbf{K 1}$ & $\mathbf{K 2}$ & $\mathbf{K 3}$ & $\mathbf{K 4}$ & $\mathbf{K 5}$ & $\mathbf{K 6}$ & $\mathbf{K} 7$ \\
\hline $\mathrm{A}+$ & $\begin{array}{c}9,8 \\
473\end{array}$ & $\begin{array}{c}9,66 \\
74\end{array}$ & $\begin{array}{c}7,50 \\
00\end{array}$ & $\begin{array}{c}7,95 \\
00\end{array}$ & $\begin{array}{c}5,69 \\
80\end{array}$ & $\begin{array}{c}5,601 \\
1\end{array}$ & $\begin{array}{c}5,77 \\
35\end{array}$ \\
\hline $\mathrm{A}-$ & $\begin{array}{c}7,3 \\
855\end{array}$ & $\begin{array}{c}7,73 \\
39\end{array}$ & $\begin{array}{c}4,50 \\
00\end{array}$ & $\begin{array}{c}6,36 \\
00\end{array}$ & $\begin{array}{c}3,41 \\
88\end{array}$ & $\begin{array}{c}1,400 \\
3\end{array}$ & $\begin{array}{c}1,92 \\
45\end{array}$ \\
\hline
\end{tabular}

d) Menentukan Jarak Tiap Alternatif dengan Solusi Ideal Positif

Untuk menentukan jarak tiap alternatif dengan solusi ideal positif, rumus yang digunakan ialah sebagai berikut.

$$
D_{i}^{+} \sqrt{\sum_{j=1}^{n}\left(y_{i}^{+}-y_{i j}\right)^{2}} ;(3)
$$

Mengambil sampel alternatif Perusahaan 1, berikut langkah perhitungan jarak alternatif Perusahaan 1.dengan solusi ideal positif.

$$
\begin{aligned}
& D^{+}=\sqrt{\begin{array}{c}
(9,848-9,848)^{2}+(9,668-9,668)^{2} \\
+(7,500-7,500)^{2}+(6,360-7,950)^{2} \\
+(3,419-5,698)^{2}+(5,601-5,601)^{2} \\
+(3,849-5,7735)^{2}
\end{array}} \\
& D^{+}=\sqrt{\begin{array}{c}
(0)^{2}+(0)^{2}+(0)^{2} \\
+(1,5900)^{2}+(2,2790)^{2}+(0)^{2}+(1,9245)^{2}
\end{array}} \\
& D^{+}=\sqrt{0+0+0} \\
& D^{+}=\sqrt{\mathbf{1 1 , 4 2 5 6 4 1 2}}=3,801836
\end{aligned}
$$

e) Menentukan Jarak Tiap Alternatif dengan Solusi Ideal Negatif

Untuk menentukan jarak tiap alternatif dengan solusi ideal positif, rumus yang digunakan ialah sebagai berikut.

$$
D_{i}^{-} \sqrt{\sum_{j=1}^{n}\left(y_{i j}-y_{i}^{-}\right)^{2}} ;(4)
$$


Langkah perhitungan jarak alternatif Perusahaan 1.dengan solusi ideal negatif ialah sebagai berikut.

$$
\begin{gathered}
D^{-}=\sqrt[\begin{array}{c}
(9,8473-7,3855)^{2}+(9,6674-7,7339)^{2} \\
+(7,5000-4,5000)^{2}+(6,3600-6,3600)^{2} \\
+(3,4188-3,4188)^{2}+(5,6011-1,4003)^{2} \\
+(3,8490-1,9245)^{2}
\end{array}]{D^{-}=\sqrt{\begin{array}{r}
(2,4618)^{2}+(1,9335)^{2}+(3)^{2}+(0)^{2} \\
+(0)^{2}+(4,2008)^{2}+(1,9245)^{2}
\end{array}}} \\
D^{-}=\sqrt{\begin{array}{r}
6,06045924+3,73842225+9+0+0 \\
+17,6467206+3,70370025
\end{array}} \\
D^{-}=\sqrt{40,1493023}=6,336348
\end{gathered}
$$

Proses perhitungan untuk memperoleh solusi ideal positif dan solusi ideal negatif juga berlaku untuk proses perhitungan alternatif lainnya, sehingga diperoleh hasil pada tabel berikut.

TABEL IX

JARAK TIAP ALTERNATIF DENGAN SOLUSI IDEAL

\begin{tabular}{|c|l|c|c|}
\hline No & Nama & D+ & D- \\
\hline 1 & Perusahaan 1 & 3,3803 & 6,3364 \\
\hline 2 & Perusahaan 2 & 5,2549 & 4,3619 \\
\hline 3 & Perusahaan 3 & 5,0089 & 5,1466 \\
\hline 4 & Perusahaan 4 & 4,5234 & 6,2066 \\
\hline 5 & Perusahaan 5 & 3,9679 & 5,9495 \\
\hline
\end{tabular}

f) Nilai Preferensi untuk Tiap Alternatif

Langkah terakhir dari metode TOPSIS ialah mencari nilai preferensi dari tiap alternatif dengan memanfaatkan rumus berikut.

$$
V_{i}=\frac{D_{i}^{-}}{D_{i}^{-}+D_{i}^{+}} ;(5)
$$

Nilai preferensi inilah yang merupakan hasil analisa dari metode TOPSIS dalam Sistem Pendukung Keputusan untuk Tender Alat Kesehatan di Rumah Sakit PKU Muhammadiyah Sekapuk Gresik.

Nilai preferensi untuk alternatif Perusahaan 1 dijelaskan sebagai berikut.

$$
\begin{aligned}
V_{x} & =\frac{6,3364}{3,3803+6,3364} \\
& =0,6521
\end{aligned}
$$

Penerapan perhitungan tersebut juga berlaku untuk alternatif lainnya, sehingga diperoleh nilai preferensi tiap alternatif yang kemudian diurutkan dari nilai tertinggi ke terendah seperti yang ditunjukkan pada tabel berikut.
TABEL XIII

NILAI PREFERENSI TIAP ALTERNATIF

\begin{tabular}{|c|l|c|}
\hline No. & \multicolumn{1}{|c|}{ Nama } & $\boldsymbol{V}_{\boldsymbol{x}}$ \\
\hline 1 & Perusahaan 1 & 0,6521 \\
\hline 2 & Perusahaan 2 & 0,4536 \\
\hline 3 & Perusahaan 3 & 0,5068 \\
\hline 4 & Perusahaan 4 & 0,5784 \\
\hline 5 & Perusahaan 5 & 0,5999 \\
\hline
\end{tabular}

\section{KESIMPULAN DAN SARAN}

Berdasarkan hasil analisis dan pembahasan yang telah dijelaskan pada bab-bab sebelumnya, maka dengan adanya sistem pendukung keputusan dengan menggunakan metode TOPSIS untuk tender alat kesehatan di Rumah Sakit PKU Muhammadiyah Sekapuk Gresik kesimpulan yang diperoleh dari penelitian ini ialah : sistem ini mampu memudahkan pihak rumah sakit dalam melakukan proses seleksi terhadap perusahaan penyedia alat / jasa kesehatan yang telah mengajukan diri sebagai peserta tender dengan mengaplikasikan metode TOPSIS dalam sistem pendukung keputusan.

Sistem ini mampu memberikan rekomendasi perusahaan peserta tender yang menjadi prioritas berupa perangkingan ke pihak rumah sakit dalam pengambilan keputusan pemenang seleksi tender tahap awal, sehingga dapat mempercepat proses tender atau pengadaan alat kesehatan yang berlangsung. Sistem pendukung keputusan ini telah mampu membantu pihak rumah sakit dalam melakukan evaluasi yang objektif dengan melakukan penilaian dari setiap kriteria yang telah ditentukan terhadap proposal penawaran yang diajukan perusahaan peserta tender calon pemenang seleksi tender tahap awal di Rumah Sakit PKU Muhammadiyah Sekapuk Gresik.

\section{DAFTAR PUSTAKA}

[1] L. M. M. Nur Ilmi Faisal, Jenny Morasa, "Analis is Sistem Pengadaan Barang dan Jasa (Penunjung Langsung) pada di Dinas Pekerjaan Umum dan Penataan Ruang Kota Manado," Ris. Akutansi Going Concern, vol. 12, no. 2, pp. 1122-1132, 2017.

[2] A. R. A. Nurchana, B. S. Haryono, and R. Adiono, "Efektivitas dalam Pengadaan Barang/Jasa (Studi terhadap Penerapan E-Procurement dalam Pengadaan Barang/Jasa di Kabupaten Bojonegoro)," J. Adm. Publik, vol. 2, no. 2, pp. 355-359, 2014.

[3] J. Kenedi, D. Lanin, Z. Agus, K. Kunci, R. Sakit, and A. Kesehatan, "Analisis Pengadaan Alat Kesehatan Di Rumah Sakit Umum Daerah Padang Pariaman Tahun 2017," vol. 7, no. Supplement 2, pp. 9-16, 2018.

[4] Karyasa, "ANALISIS FAKTOR-FAKTOR YANG MEMPENGARUHI GAGAL LELANG PENGADAAN BARANG DAN JASA ( E-PROCUREMENT ) DI 
KABUPATEN BADUNG," vol. 2, no. 1, pp. 19-27, 2014.

[5] A. K. Sari, E. Sihombing, and Solikhatun, "Sistem Pendukung Keputusan untuk Meningkatkan Kualitas Pelayanan di Bidang Kesehatan,” 2006.

[6] Y. I. Gilang Sonar Amanu, "PENGEMBANGAN SISTEM PENDUKUNG KEPUTUSAN PENGADAAN DAN PERSEDIAAN BARANG DENGAN METODE PERPETUALINVENTORYMETHOD DAN ECONOMIC ORDER QUANTITY," vol. 7, pp. 21-30.

[7] A. Y. Rahman, M. Sa'adah, F. W. Setiawan, and E. Supriyanto, "Vice Presidential Election Prediction Period 2019- 2024 using Simple Additive Weighting," pp. 5660, 2018.

[8] S. A. Denni Aldi Ramadhani, "Perhitungan Sistem pendukung keputusan penerimaan pegawai dengan metode topsis."

[9] Frieyadie, "PENERAPAN METODE SIMPLE ADDITIVE WEIGHT (SAW) DALAM SISTEM PENDUKUNG KEPUTUSAN PROMOSI KENAIKAN JABATAN," 2016.

[10] M. Tanubrata, "Evaluasi Penawaran pada Proses Pengadaan Barang."

[11] F. Riandari, P. M. Hasugian, and I. Taufik, "Sistem Pendukung Keputusan Menggunakan Metode Topsis Dalam Memilih Kepala Departemen Pada Kantor Balai Wilayah Sungai Sumatera Ii Medan," J. Inform. Pelita Nusant., vol. 2, no. 1, pp. 6-13, 2017.

[12] B. A. Benning, I. F. Astuti, and D. M. Khairina, "SISTEM PENDUKUNG KEPUTUSAN PEMBELIAN PERANGKAT KOMPUTER DENGAN METODE TOPSIS," J. Inform. Mulawarman, vol. 10, no. 2, pp. 1-7, 2015.

[13] A. Y. Rahman, M. Sa'adah, F. W. Setiawan, A. L. Hananto, and E. Supriyanto, "Access Level File using Simple Additive Weighting,” pp. 62-66, 2018. 
